\title{
Electrochemical Immunosensors and Aptasensors
}

\author{
Paolo Ugo * and Ligia M. Moretto * \\ Department of Molecular Sciences and Nanosystems, University Ca' Foscari of Venice, via Torino 155, \\ 30172 Mestre-Venice, Italy \\ * Correspondence: ugo@unive.it (P.U.); moretto@unive.it (L.M.M.); Tel.: +39-041-234-8503 (P.U.); \\ +39-041-234-8585 (L.M.M.)
}

Academic Editor: Igor Medintz

Received: 30 March 2017; Accepted: 30 March 2017; Published: 2 April 2017

\section{Introduction}

Since the first electrochemical biosensor for glucose detection, pioneered in 1962 by Clark and Lyons [1], research and application in the field has grown at an impressive rate and we are still witnessing a continuing evolution of research on this topic [2].

According to the definition recommended by IUPAC some years later [3], a biosensor is a self-contained device that is capable of providing specific quantitative or semi-quantitative analytical information using a biological recognition element (biochemical receptor) that is in direct spatial contact with the transduction element.

The easiest and perhaps most efficient way to favor the exchange of chemical information between a biomolecular recognition layer and a signal transducer is to immobilize the former directly on the surface of an electrochemical transducer, namely an electrode.

Initially, major research and application efforts were devoted to developing biocatalytic electrochemical sensors [4,5], aimed at exploiting the specificity of the reaction between an enzyme and its substrate to typically detect (in the simplest case) the latter as the analyte [6]. In the 1980s-1990s, the first examples of immunochemical reactions being used for electrochemical sensing were proposed by Heineman and Halsall [7], to be followed by the first proposal of electrochemical immunosensors where antibodies were immobilized on the electrode surface [8].

These biosensors exploit the specificity of the antigen $(\mathrm{Ag})$-antibody $(\mathrm{Ab})$ interaction in order to detect one of the two partners as the analyte. For instance, the Ag can be immobilized on the electrode to capture the $\mathrm{Ab}$ or vice-versa. In order to achieve electrochemical detection by this approach, it is necessary to use a label which should be electroactive itself or able to generate or consume an electroactive molecule. By exploiting the long-lasting know-how developed for ELISA assays, the most commonly used labels in electrochemical immunosensors are enzyme labels. Following this approach, many sensors have been developed to detect a number of disease markers [9].

Recent research trends in the field of affinity biosensors are indeed moving beyond the above described ELISA-based approach, and new directions are being explored.

On one side, many studies are aimed at developing and applying novel capture agents, not necessarily belonging to the antibody category. Aptamers represent a successful example of efficient capture molecules as an alternative to antibodies. Aptamers are single-stranded oligonucleotides which act as biorecognition elements for proteins and other molecules. An aptamer for a specific target is selected from a large pool of random RNA or DNA sequences by the so-called SELEX (systematic evolution of ligands by exponential enrichment) methodology and is amplified by the polymerase chain reaction $[10,11]$.

On the other hand, the possibility to avoid the use of enzyme labels appears very attractive in order to simplify detection schemes, avoiding complex functionalization procedures. 
All this recent progress in the field of affinity biosensors has also led to the applications of affinity biosensors being widened to areas not necessarily of biomedical interest, extending to environmental [12] and food control [13].

\section{The Special Issue}

This Special Issue compiles eleven contributions and offers a platform on which to present recent developments in the field of electrochemical immunosensors and aptasensors, outlining future prospects and research trends.

The use of advanced capturing agents as an alternative to "classical" antibodies constitutes the focus of three original research articles. Marrazza and coworkers [14] propose the use of affibodies immobilized on magnetic particles to detect, with screen printed electrodes, the human epidermal growth factor receptor 2 (HER2) which is overexpressed by breast cancer cells. De Wael et al. [15] study the immobilization of aptamers on core-shell nanoparticles for improving the electrochemical detection of bacteria. Aptamers are also studied by Casalis and coworkers [16] who exploit an approach based on atomic force microscopy to control the bioaffinity properties of the sensor at the nanoscale. A miniaturized electrochemical cell for electrochemical impedance spectroscopy is developed and tested for thrombin detection.

Three review papers set the state-of-the-art on the use of aptamers for different biosensing purposes. The review by Oliveira-Brett and Chiorcea-Paquim [17] deals with the electrochemical characterization of four-stranded guanine structures (G-quadruplex), discussing the development of G-quadruplex aptasensors and hemin/G-quadruplex biosensors with peroxidase activity. Szunerits, Vasilescu et al. [18] review recent research on the development of aptamers-based electrochemical sensors suitable to detect lysozyme, an ubiquitous protein with antibacterial activity; this protein is also a potential biomarker for several diseases and can act as an allergen in foods. The review by $\mathrm{Qi}, \mathrm{Xu}$ and coworkers [19] presents and discusses recent research aimed at combining aptasensing with stripping voltammetry. This combination offers interesting analytical prospects for the sensitive detection of a variety of analytes, from small biomolecules to proteins and cancer cells.

Electrochemical detection methods, as alternatives to voltammetry, amperometry or even electrochemical impedance spectroscopy, are discussed by de Moraes and Kubota [20], who reviewed the recent literature on immunosensors based on field effect transistors (FETs). The electrical signal of FET immunosensors is generated as a result of the antibody-antigen conjugation. FET biosensors allow real-time and rapid response, exhibiting high sensitivity and selectivity for analysis in small sample volume.

The applications of affinity sensors to food analyses and control are also a hot topic and, in this Special Issue, four papers deal with the exploitation of the analytical potentialities of immunosensors for this purpose. The review by Marty and coworkers [21] presents the state-of-the-art in the field of aflatoxin (AF) detection with affinity biosensors. Mycotoxins are toxic secondary metabolites produced by fungal species that can colonize and contaminate crops. Among them, aflatoxins (AFs) are of major significance because of their possible presence in many food commodities, thus constituting a potential threat to human health. The paper discusses and compares the characteristics and analytical performances of sensors for AF detection based on antibodies or aptamers as capture reagents.

Three research papers deal with the development of immunosensors for food control, trying to push the frontiers by using non-conventional electrode systems.

Pingarron, Campuzano and coworkers [22] present a novel magnetic beads-based immunosensing approach for the rapid and simultaneous determination of the main peanut allergenic proteins, namely, Ara h 1 and Ara h 2. The use of dual screen-printed carbon electrodes and the $\mathrm{H} 2 \mathrm{O} 2 /$ hydroquinone system allowed interestingly low detection limits to be reached, suitable for detecting the two allergens in food extracts and wheat flour.

Yamanaka, Foguel et al. [23] propose the use of the so-called CD-trodes as transducers for the label-free immunosensing of aflatoxin B1 (AFB1). The CD-trodes are obtained by recycling 
Au-compact discs (CDs), by the suitable removal of the polycarbonate outer layer. The electrode is then functionalized with anti-AFB1 using a self assemble monolayer of lipoic acid as an anchoring agent.

Moretto, Ugo et al. [24] apply ensembles of nanoelectrodes (NEEs), prepared by template $\mathrm{Au}$ deposition in nanoporous membranes, to detect, in food integrators, immunoglobulin IgY from hen-eggs yolk. Anti-IgY is immobilized on the polycarbonate templating membrane which surrounds the Au nanoelectrodes, achieving high antibody loadings while keeping unaltered the extremely low detection limits typical of NEEs.

Acknowledgments: We would like to thank all authors who contributed with their excellent papers to this Special Issue (SI). We thank the anonymous reviewers for their fundamental help in assuring the high quality of the SI. We are grateful to the Chemosensors Editorial Office for giving us this opportunity and, in particular, to Linda Wang for her continuous support in managing and organizing this SI.

\section{References}

1. Clark, L.C., Jr.; Lyons, C. Electrode systems for continuous monitoring in cardiovascular surgery. Ann. NY Acad. Sci. 1962, 102, 29-45. [CrossRef] [PubMed]

2. Ronkainen, N.J.; Halsall, H.B.; Heineman, W.R. Electrochemical biosensors. Chem. Soc. Rev. 2010, 39, 1747-1763. [CrossRef] [PubMed]

3. Thevenot, D.R.; Toth, K.; Durst, R.A.; Wilson, G.S. Electrochemical biosensors: Recommended definitions and classifications. Pure Appl. Chem. 1999, 71, 2333-2348. [CrossRef]

4. Turner, A.; Karube, I.; Wilson, G.S. Biosensors: Fundamentals and Applications; Oxford University Press: Oxford, UK, 1987.

5. Cunningham, A.J. Introduction to Bioanalytical Sensors; John Wiley \& Sons: West Sussex, UK, 1998.

6. Bartlett, P.N. Bioelectrochemistry, Fundamentals, Experimental Techniques and Applications; John Wiley \& Sons: West Sussex, UK, 2008.

7. Heineman, W.R.; Halsall, H.B. Antibodies-production, functions and applications in biosensors strategies for electrochemical immunoassay. Anal. Chem. 1985, 57, 1321A-1331A. [CrossRef] [PubMed]

8. Killard, A.J.; Deasy, B.; O'Kennedy, R.; Smyth, M.R. Antibodies: Production, functions and applications in biosensors. TrAC Trends Anal. Chem. 1995, 14, 257-266. [CrossRef]

9. Rusling, J.F. Nanomaterials-based electrochemical immunosensors for proteins. Chem Rec. 2012, 12, $164-176$. [CrossRef] [PubMed]

10. Ellington, A.D.; Szostak, J.W. In vitro selection of RNA molecules that bind specific ligands. Nature 1990, 346, 818-822. [CrossRef] [PubMed]

11. Tierk, C.; Gold, L. Systematic evolution of ligands by exponential enrichment: RNA ligands to bacteriophage T4 DNA polymerase. Science 1990, 249, 505-510. [CrossRef]

12. Mascini, M. Affinity electrochemical biosensors for pollution control. Pure Appl. Chem. 2001, 73, 23-30. [CrossRef]

13. Scognamiglio, V.; Arduini, F.G.; Palleschi, G.; Rea, G. Biosensing technology for sustainable food safety. TrAC Trends Anal. Chem. 2014, 62, 1-10. [CrossRef]

14. Ilkhani, H.; Ravalli, A.; Marrazza, G. Design of an affibody-based recognition strategy for human epidermal growth factor receptor 2 (HER2) detection by electrochemical biosensors. Chemosensors 2016, 4, 23. [CrossRef]

15. Hamidi-Asl, E.; Dardenne, V.; Pilehvar, S.; Blust, R.; De Wael, V. Unique properties of core shell Ag@Au nanoparticles for the aptasensing of bacterial cells. Chemosensors 2016, 4, 16. [CrossRef]

16. Bosco, A.; Ambrosetti, E.; Mavri, J.; Capaldo, P.; Casalis, L. Miniaturized aptamer-based assays for protein detection. Chemosensors 2016, 4, 18. [CrossRef]

17. Chiorcea-Paquim, A.M.; Oliveira-Brett, A.M. Guanine quadruplex electrochemical aptasensors. Chemosensors 2016, 4, 13. [CrossRef]

18. Vasilescu, A.; Wang, Q.; Li, M.; Boukherroub, R.; Szunerits, S. Aptamer-based electrochemical sensing of lysozyme. Chemosensors 2016, 4, 10. [CrossRef]

19. Qi, W.; Wu, D.; Xu, G.; Nsabimana, J.; Nsabimana, A. Aptasensors based on stripping voltammetry. Chemosensors 2016, 4, 12. [CrossRef]

20. De Moraes, A.C.M.; Kubota, L.T. Recent trends in field-effect transistors-based immunosensors. Chemosensors 2016, 4, 20. [CrossRef] 
21. Sharma, A.; Goud, K.Y.; Hayat, A.; Bhand, S.; Marty, J.L. Recent Advances in electrochemical-based sensing platforms for aflatoxins detection. Chemosensors 2017, 5, 1. [CrossRef]

22. Ruiz-Valdepenas Montiel, V.; Torrente-Rodríguez, R.M.; Campuzano, S.; Pellicanò, A.; Reviejo, Á.J.; Cosio, M.S.; Pingarrón, J.M. Simultaneous determination of the main peanut allergens in foods using disposable amperometric magnetic beads-based immunosensing platforms. Chemosensors 2016, 4, 11. [CrossRef]

23. Foguel, M.V.; Giordano, G.F.; de Sylos, C.M.; Carlos, I.Z.; Ferreira, A.A.P.; Benedetti, A.V.; Yamanaka, H. A low-cost label-free $\mathrm{AFB}_{1}$ impedimetric immunosensor based on functionalized $\mathrm{CD}$-trodes. Chemosensors 2016, 4, 17. [CrossRef]

24. Gaetani, C.; Ambrosi, E.; Ugo, P.; Moretto, L.M. Electrochemical immunosensor for detection of IgY in food and food supplements. Chemosensors 2017, 5, 10. [CrossRef]

(C) 2017 by the authors. Licensee MDPI, Basel, Switzerland. This article is an open access article distributed under the terms and conditions of the Creative Commons Attribution (CC BY) license (http://creativecommons.org/licenses/by/4.0/). 